\title{
The Political Economy of Deposit Insurance
}

\author{
Luc Laeven*
}

World Bank and CEPR

\begin{abstract}
This paper uses a political economy framework to analyze cross-country differences in deposit insurance coverage. It finds supporting evidence of the significance of private interest theories in explaining coverage of deposit insurance. Deposit insurance coverage is significantly higher in countries where poorly capitalized banks dominate the market and in countries where depositors are poorly educated. The analysis does not find that coverage is significantly related to political-institutional variables, such as the degree of democracy or restraints on the executive, or to proxies for the general level of institutional development, such as per capita income or property rights. These results provide evidence in support of the private interest view, according to which risky banks lobby for extensive coverage.
\end{abstract}

Keywords: Deposit Insurance, Political Economy

World Bank Policy Research Working Paper 3247, March 2004

The Policy Research Working Paper Series disseminates the findings of work in progress to encourage the exchange of ideas about development issues. An objective of the series is to get the findings out quickly, even if the presentations are less than fully polished. The papers carry the names of the authors and should be cited accordingly. The findings, interpretations, and conclusions expressed in this paper are entirely those of the authors. They do not necessarily represent the view of the World Bank, its Executive Directors, or the countries they represent. Policy Research Working Papers are available online at http://econ.worldbank.org.

* Contact details: World Bank, 1818 H Street, 20433 Washington DC, Phone: (202) 458-2939, Fax: (202) 522-2031, E-mail: Llaeven@worldbank.org. I am grateful to Mark Carey, Stijn Claessens, Robert DeYoung, George Hanc, Jim Hanson, Ed Kane, Lemma Senbet, Phil Strahan, Haluk Unal, and participants at the FDIC/JFSR conference on Finance and Banking: New Perspectives for helpful discussions and/or comments, and to Ying Lin and Guillermo Noguera for research assistance. 


\section{Introduction}

Since 1934, the year when the United States introduced deposit insurance, a large number of countries have followed the U.S. example and adopted deposit insurance, with a strong surge in recent years among developing countries. Yet, a large number of countries have thus far not decided to adopt deposit insurance, and deposit insurance schemes vary significantly from country to country in coverage and safeguards.

Deposit insurance design seems to be very much an area in which our understanding could greatly benefit from the use of a political economy approach because the process underlying the design is a complex interplay of various political constituencies with often conflicting interests. Deposit insurance not only affects banks' depositors, but also banks' other stakeholders, such as shareholders, creditors, bank managers, the deposit insurance agency, the government, and taxpayers. Not only will interests differ among these various groups of stakeholders, but interests may also differ within each group. For example, not all depositors will have the same interest in deposit insurance. If coverage is limited, large depositors may be less interested in deposit insurance than small depositors. Similarly, if deposit insurance is not risk-sensitive, banks that perceive themselves to be of below-average risk may be less interested in the adoption of deposit insurance than risky banks.

The political motives for the implementation of deposit insurance typically include the provision of protection for small depositors and the enhancement of public confidence in the banking system and systemic financial stability. These goals come at large costs, both direct costs in the form of a tax and indirect costs due to increased moral 
hazard in the behavior of banks. As a result, deposit insurance will typically be favored by "weak parties", such as small depositors and risky banks.

This paper empirically investigates how cross-country differences in political, regulatory, and institutional setup affect the size of deposit insurance coverage, measured as the ratio of coverage limit per depositor to per capita income. It finds that deposit insurance coverage is higher in countries where poorly capitalized banks dominate the market and in countries where depositors are poorly educated. It does not find that coverage is related to political-institutional variables, such as the degree of democracy or restraints on the executive, and to proxies for the general level of institutional development, such as per capita income or property rights. These results provide evidence in support of the private interest view, according to which risky banks lobby for extensive coverage.

The paper proceeds as follows: Section 1 reviews some of the related literature. Section 2 outlines hypotheses about the factors that affect the support for extensive coverage of deposit insurance. This section also presents the data and the variable definitions. Section 3 presents the empirical model and results, and section 4 concludes.

\section{Related Literature}

Deposit insurance at a national level was first introduced in the United States in 1934, in reaction to the loss of public confidence during the Great Depression of 1930-33. Although the majority of U.S. Congress did not subscribe to the idea of deposit insurance until the crisis in 1933, the political change that led to the adoption of deposit insurance was the result of widespread losses suffered by depositors. 
The introduction of deposit insurance in the United States is an informative episode about the political economy of deposit insurance reforms. Calomiris and White (1994) argue that the smaller and weaker unit banks in the United States had long supported deposit insurance, and that they would have never been able to successfully lobby for the introduction of deposit insurance against the opposition of the politically more powerful, stronger and larger urban branching banks had the Great Depression not occurred and eroded public confidence in the banking system as a whole. Economides, Hubbard and Palia (1996) also argue that the introduction of deposit insurance in the United States was instituted for the benefit of the small, unit banks.

Kane and Wilson (1998), on the other hand, show that large banks' share prices benefited most from the introduction of deposit insurance. They argue that the broadening shareholder distribution of large banks during the late 1920s had undermined monitoring incentives by large-bank shareholders, and that deposit insurance restored depositor confidence.

With deposit insurance in place, the smaller and weaker banks continuously pressed for increases in the coverage. Prompted by increased competition from the emerging credit unions and thrifts, coverage levels were raised at various moments during the post-Depression period and deposit insurance was spread to all U.S. deposittaking institutions (White, 1998).

Before the introduction of nationwide deposit insurance in the United States in 1934, several states had already established depositor protection schemes. White (1981) shows that the main factor influencing the adoption of deposit insurance by a state was 
the structure of its banking industry. The support for deposit insurance was stronger in states where small unit banks were dominant than in states with large banks.

The U.S. experience may be somewhat unique because of the existence of statelevel differences in banking structures resulting from differences in state-level restrictions on bank branching. Some states allowed branch banking, while others preferred unit banking. As a result, certain states had a much larger share of small banks. Nevertheless, the U.S. experience does show that support for deposit insurance will depend on the banking structure of the country and is likely to be greater in banking systems where weak institutions hold a large share of the market. However, whether small banks are perceived to be riskier than large banks will depend on country circumstances. The U.S. experience also suggests that politicians may become more inclined to adopt deposit insurance in the wake of a financial crisis, when there is a widespread loss of public confidence in the banking system and weak banks are able to gain considerable interest.

The adoption of compulsory deposit insurance in Canada in 1967 was also in reaction to a loss in confidence in the sound practice of deposit-taking institutions, despite the protests of Canada's large banks that did not want to cross-subsidize their smaller rivals, which were perceived to be riskier. In 1985, two banks in Alberta failed, confirming the concerns raised earlier by the country's major banks and causing a depletion of the deposit insurance fund. The failed banks were bailed out at a large cost to the taxpayer (see Giammarino, Schwartz and Zechner (1989) for estimates of the degree of cross-subsidization taking place among Canadian commercial banks during the period 1980-1985 due to flat-rate deposit insurance premiums). 
The U.S. and Canadian experiences suggest that international differences in the setup of deposit insurance may be best explained by applying a political economy framework. Economists have broadly taken two approaches to analyzing policy outcomes: the public interest view and the private interest view (see Kroszner and Strahan (2001) for a more detailed discussion). The public interest theory of regulation argues that regulatory intervention occurs in the interest of the public at large (Joskow and Noll, 1981). The public interest rationale for deposit insurance includes the protection of small, uninformed depositors and the stability of the banking system (Diamond and Dybvig, 1983). The private interest theory of regulation describes the regulatory process as one of interest group competition, in which well-organized or powerful groups exert pressure on politicians and regulators for regulatory intervention that would allow those groups to capture rents at the expense of more dispersed groups (Stigler, 1971, Peltzman, 1976, and Becker, 1983).

In the financial services industry, competition among organized interests is particularly typical as financial institutions pressure politicians for regulations that increase their franchise values (Kroszner and Stratmann, 1998). According to the private interest view, deposit insurance is most likely to be favored by the riskier banks because they would receive a net subsidy at the expense of the safer banks in the presence of explicit deposit insurance. Lobbying for deposit insurance in the United States has historically been consistent with this pattern of relative benefits (Kroszner, 1998).

A key challenge to the public interest theory is that some forms of bank regulation are difficult to understand from a welfare-maximizing point of view. Deposit insurance systems that exacerbate moral hazard problems are generally difficult to rationalize on 
public interest grounds (Kane, 1996), unless the benefits of deposit insurance are so large that they exceed the cost of increased moral hazard.

It is important to note that the public interest and private interest theories need not be mutually exclusive, and that both theories can be consistent with certain policy outcomes. ${ }^{1}$ Nevertheless, each theory captures an important element in the political decision-making process, and our empirical work will therefore try - to the extent possible - to assess their relative importance.

Although interest group theories have long been applied to the fields of public economics (including the areas of fiscal policy and public debt issue) ${ }^{2}$, monetary economics $^{3}$, and international trade ${ }^{4}$ (see Persson and Tabellini (2000) and Grossman and Helpman (2001) for extensive overviews), only recently have such theories been applied to finance topics (see Pagano and Volpin (2001a) for an overview). For example, Kroszner and Stratmann (1998) and Kroszner and Strahan (2001) have applied interest group theories to banking, Bolton and Rosenthal (2002) to sovereign debt renegotiation, Pagano and Volpin (2001b) to corporate governance, and Perotti and Volpin (2003) to firm entry. To our knowledge, our paper is the first to apply such tools in an international context to the area of deposit insurance.

Our paper is related to work by Kroszner and Strahan (2001), who study whether interest group theories can explain the voting outcomes in the U.S. House of Representatives on the Wylie Amendment on the limitation of deposit insurance to a

\footnotetext{
${ }^{1}$ Both public and private interests are driven by beliefs and ideology (Poole and Rosenthal, 1997) and the institutional arrangements of the decision-making process (North, 1990).

${ }^{2}$ See, for example, Alesina and Tabellini (1990).

${ }^{3}$ See, for example, Barro and Gordon (1983).

${ }^{4}$ For example, Krueger (1974) describes economies as rent-seeking societies and applies private interest theories to the area of trade, and Grossman and Helpman (1995) use a model of political lobbying to study free-trade agreements.
} 
single account per bank. They find that limits to deposit insurance were opposed to by U.S. states where small banks had a large share of the market and by states with a large proportion of people over 65 years of age. The amendment was favored by states where banks could sell insurance products and where the insurance industry was relatively large. Political-institutional variables, such as political party structure and ideology, on the other hand, did not explain much of the variation beyond these private interest variables. $^{5}$

In explaining cross-country variation in the support for deposit insurance, institutional factors seem to be particularly important. Previous research has shown that the moral hazard problems associated with deposit insurance tend to be exacerbated in countries with weak institutional environments (Demirgüç-Kunt and Kane, 2002), while the detrimental impact of explicit deposit insurance is largely offset in countries with strong institutional environments (Hovakimian, Kane, and Laeven, 2003). Public interest theory would therefore imply that deposit insurance should be limited in countries with weak institutional arrangements, as excessive risk-shifting behavior of banks is not in the public interest. On the other hand, private interest theory would imply that such environments are more prone to bribery and lobbying by private interest parties, resulting in a broad coverage of deposit insurance. ${ }^{6}$

\footnotetext{
${ }^{5}$ Our work is also somewhat related to the literature on the political economy of social security and government pension systems. For example, Mulligan and Sala-i-Martin (1999) show in an interest group model that the elderly can successfully lobby for larger social security programs. Mulligan, Gil, and Sala-iMartin (2002) study the effect of democracy on the size and design of social security systems in different countries. While social security budgets tend to be significantly higher in countries with a larger share of population with age over 65 , they do not find a significant relationship between the degree of democracy and the size of social security.

${ }^{6}$ Political economy tools may also help improve our understanding of why deposit insurance is underpriced in most countries. In countries with explicit deposit insurance, deposit insurance is underpriced if the deposit insurer charges less for its services than the estimated opportunity-cost value of these services. Underpricing of deposit insurance services is a sign that banks extract deposit-insurance subsidies. Since
} 


\section{Data and Hypotheses}

Our empirical work focuses on the coverage of deposit insurance. In this section, we describe the factors that may drive the political outcome on the coverage of deposit insurance, the definitions of the regression variables, and the sources of the data. Some of the variables we consider will help us to differentiate between public and private interest theories, while others will be consistent with both theories. We will measure the effect of political-institutional factors relative to the proxies for other country characteristics. Our hypotheses will relate the size of deposit insurance coverage across countries to the proxies we describe below. Most of these measures are similar to the ones used by Kroszner and Strahan (2001) in their study on the determinants of political support for the amendment on the coverage of deposit insurance in the United States, and we will follow their approach as closely as possible to enhance comparability of their results with those obtained in our work. Naturally, the proxies used and results obtained will differ because we analyze data from many countries rather than just U.S. data.

First, we control for the political-institutional setup of the country. The voices of minorities are more likely to be heard in political systems that are less autocratic (or more democratic). As a result, countries with these political arrangements are more likely to support high coverage limits of deposit insurance. While the views of the politicians may simply reflect the economic interests of the constituents in the country (Peltzman, 1976),

large banks typically do not consider deposit insurance to be in their interest, they will (typically successfully) lobby for low premiums. Under flat-rate deposit insurance, which is the norm in most countries, premium rates will often be set such that they are affordable for the smaller banks and acceptable for the larger banks. As a result, deposit premiums will often be set below the actuarially "fair" value of deposit insurance, and deposit insurance will be subsidized. A large literature has compared actual premiums with estimated actuarially fair values, mostly based on the option pricing model introduced by Merton (1977) and adapted by Ronn and Verma (1986), and has found existing deposit insurance programs to be underpriced in most countries. We refer to Laeven (2002b) for a review of this literature. 
we consider several political variables to adjust for any independent influence of party politics. First, we construct a variable POLITY that is a composite measure of the general openness of political institutions in the country. This variable is calculated by taking the average for the years 1990-99 of the Polity IV composite index of the country. Polity IV is the updated version of the cross-country database on political regime characteristics and transitions during the period 1800-2002. The Polity database was originally designed by Ted Robert Gurr and has been updated by Monty Marshall and Keith Jaggers. The database is maintained at the Center for International Development and Conflict Management of the University of Maryland. This database has been widely used by researchers as a source of data on political-institutional characteristics.

We also construct a variable DEMOC that is the average for the years 1990-99 of the Polity IV democracy index, and a variable AUTOC that is the average for the years 1990-99 of the Polity IV autocracy index. DEMOC ranges from 0 to 10 with a higher score indicating more democracy (and general openness of political institutions). AUTOC also ranges from 0 to 10 with a higher score indicating a more autocratic government (and general closedness of political institutions). The Polity IV composite index equals the difference between the Polity IV democracy index and the Polity IV autocracy index. POLITY ranges from -10 to 10 with a higher score indicating more democracy and a lower score indicating more autocracy. The polity index is based on measures of the degree of competitiveness of political participation, the regulation of political participation, the openness and competitiveness of executive recruitment, and constraints on the chief executive. 
We also construct a variable XCONST that is the average for the years 1990-99 of the Polity IV sub-index on executive constraints. XCONST measures the extent of institutionalized constraints on the decision-making powers of chief executives. XCONST ranges from 0 to 10 with a higher score indicating less de facto operational independence (and more accountability) of the country's chief executive. XCONST captures the extent to which the political system enables minorities or non-elites to influence political elites in regular ways.

Next, we construct a variable COALITION that takes a value of one if the government of the country is a coalition government, and zero otherwise. The variable COALITION is averaged for the years 1975-97 and is based on data collected by the World Bank. For more details on this database, see Beck et al. (2001). Unfortunately, we do not have cross-country data on political campaign contributions from interest groups, unlike Kroszner and Strahan (2001) in their study of state-level deposit insurance limits in the United States. Therefore, we cannot control for the effect that money contributions may have on the voting patterns of politicians.

Second, we control for structural differences within the banking industry. Private interest theory emphasizes how different interest groups can provide funds and votes to politicians who, in turn, control the regulatory decision to raise the coverage level of deposit insurance. Private interest theory thus predicts that support for high coverage levels is more likely in countries with greater political influence of risky banks relative to that of safe banks. Public interest theory, on the other hand, would imply that support for high deposit insurance coverage is less likely in countries where the share of risky banks is large because the social costs of deposit insurance are directly related to the size of the 
protected groups of risky banks. The social costs of (extensive) deposit insurance include deadweight losses associated with reduced competition and increased moral hazard relative to banking without (extensive) deposit insurance (Kroszner and Strahan, 2001).

In the United States, small banks have lobbied to raise the coverage of deposit insurance since the adoption of national deposit insurance in 1934 because a higher coverage would protect them from competition from larger and more efficient banks (Calomiris and White, 1994). However, whether small banks are riskier than large banks depends, among others, on country circumstances. In many countries, the largest banks are often state-owned and perceived to be riskier than the smaller, private banks in the country. Also, private monitoring incentives of large, private banks may be negatively affected by the fact that these banks tend to have more dispersed ownership, and as a result these banks may take more risk (Kane and Wilson, 1998, and Laeven, 2002a).

Our proxy for the strength of the small banks is the fraction of banking assets in small banks in each country. We refer to this variable as SMLBNK. We define banks as small if they have assets below the median size of all banks operating in the country. By allowing the definition of SMLBNK to vary across countries, we take into account crosscountry heterogeneity in the size of banks.

We also include a variable LOWCAP that is the fraction of banking assets in banks with below median capital-asset ratio for all banks operating in the country. This measure captures the relative size of poorly capitalized banks. Private interest theory predicts that poorly-capitalized banks are more likely to favor high levels of deposit insurance coverage than well-capitalized banks because poorly-capitalized banks are perceived to be riskier. Public interest theory, on the other hand, predicts that politicians 
in countries with a large number of poorly capitalized banks are more likely to oppose high levels of deposit insurance coverage because the risk of bank failure and bailout increases in such environments. We obtain data on bank size and bank capital from BANKSCOPE, a commercial database of financial statements of international banks maintained by Bureau Van Dijk. We use data for the year 1999.

As an alternative measure of bank risk, we use NPLAST, which is defined as the ratio of nonperforming loans to total loans. Data on the share of nonperforming loans come from Barth, Caprio and Levine (2004). The data refer to year-end 1999. Public interest theory would imply that politicians in countries with a higher share of nonperforming loans are more likely to oppose a broad coverage of deposit insurance because the risk of bank failure and bailout increases in such environments. On the other hand, banks with a large portfolio of bad assets will be a powerful lobby for extensive deposit insurance. Private interest theory, therefore, predicts that countries with a larger share of nonperforming loans are more likely to have broad coverage of deposit insurance.

Third, we control for the level of education in the country. We expect that education has a negative impact on the level of deposit insurance coverage because more educated citizens are more likely to understand that limiting deposit insurance reduces moral hazard. However, the effect could be ambiguous because the level of education may be correlated with the degree to which people use the banking system and, therefore, care about their claims. Our proxy for the level of education is SCHOOL, which is the gross secondary school enrollment in the country. In a robustness test, we use the literacy rate of the adult population in the country as a proxy for the education level in the 
country. The data on school enrollment and literacy rates are from the World Bank's World Development Indicators database. For each country, we use the schooling and literacy rates for the year 2000 .

Fourth, we control for the overall level of economic development. The research summarized in Demirgüç-Kunt and Kane (2002) suggests that high deposit insurance limits are more feasible in countries with better institutional environments because good institutions serve to mitigate the moral hazard effects of explicit deposit insurance. The public interest view would thus suggest that the level of deposit insurance coverage is likely to be higher in countries with better institutional environments. To the extent that such systems also bring about safer banks, the private demand for deposit insurance would be lower in these countries. Private interest theory thus predicts that coverage levels of deposit insurance are likely to be lower in countries with a high level of economic development. As measure of the overall level of economic development, we include per capita GDP in 1995 expressed in 1995 U.S. dollars. We refer to this variable as GDPCAP. In the regressions, we use the logarithm of this variable. The data on per capita income are from the World Bank's World Development Indicators database.

Fifth, we control for the effect of differences in demographics of the population. Since elderly people typically have more liquid assets than younger people and tend to mainly use bank deposits as a savings vehicle, private interest theory predicts that legislators from countries with a larger share of elderly people are more likely to vote in favor of high coverage limits of deposit insurance. As proxy for the importance of elderly constituents we use the variable POP65, which is the share of the total population in the country with age 65 and above at year-end 2000. The data on the share of the population 
with age 65 and above are from the World Development Indicators database of the World Bank.

In a robustness test, we also control for the ability of banks to engage in insurance-related activities. Although insurance companies are not directly subject to deposit insurance regulation, they are indirectly affected if banks can sell insurance products because they produce substitute products that directly compete with the regulated banking industry. A number of countries permit commercial banks to sell insurance. In those countries, private interest theory predicts that the insurance industry lobby would be particularly concerned about deposit insurance because it may give banks a competitive edge in the provision of certain financial services. Thus, private interest theory predicts that coverage levels of deposit insurance would be smaller in countries where banks may sell insurance. The public interest view suggests that activity restrictions prevent the exploitation of scope economies and, therefore, have negative wealth effects. Deposit insurance could compensate banks for this opportunity cost. Public interest theory thus also predicts that deposit insurance coverage is lower in countries where banks can sell insurance. Alternatively, if it is in the public interest to protect the franchise value of banks from competing industries, we may find the opposite link. Particularly in countries with weak banking systems, it could be in the interest of the public to restrict competition among banks. To measure the effects of the rival insurance industry, we use a variable RESTRICT that captures the degree to which the country restricts banks to sell insurance. RESTRICT can take values between 0 and 3 , with a higher score indicating more restrictions. A score of 3 indicates that banks are prohibited to sell insurance, and a score of 0 indicates that there are no restrictions on banks to sell 
insurance. Data to construct this variable come from Barth, Caprio and Levine (2004). The data refer to the year 1999 or 2000.

We also consider the financial structure of the country, i.e., whether the country's financial system is more market-based or bank-based. STRUCTURE is a measure of the size of stock markets relative to that of banks. To measure the size of the domestic stock market, we use the market capitalization ratio, which equals the value of domestic equities listed on domestic exchanges divided by GDP. To measure the size of banks, we use the private bank credit ratio, which equals the value of total bank credit to the private sector divided by GDP. STRUCTURE equals the logarithm of the market capitalization ratio divided by the private bank credit ratio. We use the average of this variable over the years 1995-99 as proxy for financial system structure. A higher score indicates a more market-based system, and a lower score indicates a more bank-based system. This variable has previously been used as a measure of financial system structure by Levine (2001), among others. Because he calculates this variable over the period 1980-95, the Levine dataset has data on only 31 of the countries with explicit deposit insurance in our dataset. We therefore update the financial structure variable for the countries in our sample using data on stock market capitalization and credit to the private sector for the years 1995-99, increasing the number of countries with explicit deposit insurance for which data on financial structure are available from 31 to 52 . Data on stock market capitalization and private bank credit ratios come from the World Development Indicators database of the World Bank.

Next, we control for the contracting environment of the country. Since moral hazard problems associated with deposit insurance tend to be exacerbated in countries 
with weak contracting environments (Demirgüç-Kunt and Kane, 2002), public interest theory predicts that countries with poor contracting environments are less likely to have high levels of deposit insurance coverage. Since countries with poor contracting environments tend to have weaker banks, private interest theory predicts that countries with poor contracting environments are more likely to have high coverage levels, as a result of the lobby of the constituents representing these weak banks. As a proxy for the contracting environment in the country, we use an index of property rights from the Index of Economic Freedom developed by the Heritage Foundation. PROPERTY is the score of this index of property rights for the year 1999. The index ranges from 1 to 5 with a lower score indicating a better protection of private property. The score is based on the degree of legal protection of private property, the probability that the government will expropriate private property, and the country's legal protection of private property. This broad index of property rights is available for a large set of countries and has been used by other researchers (e.g., La Porta, Lopez-de-Silanes, Shleifer, and Vishny, 1999).

Data on the adoption and coverage of explicit deposit insurance come from Garcia (2000), Demirgüç-Kunt and Sobaci (2001) and Laeven (2002b). Because the data are missing for a number of countries that recently adopted deposit insurance and because the data on coverage is outdated for a number of countries, we update and supplement the data for a number of countries using country sources (mainly deposit insurance laws obtained from central banks and official deposit insurance agencies). Our analysis will use two variables. The first variable, COVGDP, measures the size of deposit insurance coverage and is calculated as the ratio of coverage limit per deposit to GDP per capita at year-end 2000. We express coverage limits in terms of per capita GDP to enhance 
comparability of coverage across countries with different levels of economic development. Because the average deposit tends to be larger in more developed countries and because governments typically intend to insure at least a certain minimum share of total deposits (or depositors), developed countries tend to have higher coverage limits than developing countries.

For robustness, we use an alternative measure of the size of deposit insurance coverage, COVDEP, which is calculated as the ratio of coverage limit per deposit to total deposits per capita at year-end 2000. By comparing coverage limits to the value of deposits, this variable captures the degree of coverage per depositor.

For countries that have adopted explicit deposit insurance, we also collect information on the year of adoption. The variable AGE measures the age of the explicit deposit insurance scheme in the country, and is calculated as 2000 minus the year during which the country introduced explicit deposit insurance. The source of the variable AGE is Garcia (2000), Demirgüç-Kunt and Sobaci (2001) and Laeven (2002b). AGE takes values between 0 and 66. The value for the United States is 66 since the United States was the first country to introduce explicit deposit insurance in 1934. In a robustness test, we use a Heckman selection model to control for potential sample selection bias. The first-stage of the selection model uses a variable DI, which takes a value of one if the country has explicit deposit insurance at year-end 2000, and zero otherwise. This variable identifies whether the country has explicit or implicit deposit insurance.

Our dataset is limited by the number of countries for which we have data on the existence and coverage of deposit insurance. We have such data for 111 countries. Most of our empirical results are based on the sub-sample of countries with explicit deposit 
insurance rather than the total sample of countries. The number of countries included in our regressions varies somewhat because we miss data for some of the control variables. The data of the main regression variables are shown in Annex 1. Table 1 shows that of the 111 countries in our sample, 69 countries (or 64 percent) have explicit deposit insurance. To our knowledge, this represents the complete list of countries with explicit deposit insurance as of year-end 2000.

The sample statistics of the regression variables are reported in Table 2. For most countries in our sample, GDP per capita exceeds total deposits per capita. The average value of COVDEP is, therefore, significantly larger than the average value of COVGDP. We also find that there is a wide variation across countries in the size of deposit insurance coverage as measured by COVGDP and especially COVDEP.

\section{Empirical Results}

In order to determine the influence of the political-institutional and other factors described above on the coverage level of deposit insurance, we use multiple regression analysis. This approach will also enable us to empirically investigate the relative importance of private and public interest theories in explaining cross-country variation in the coverage of deposit insurance. The dependent variable is COVGDP, which is the ratio of coverage limit per deposit to per capita GDP at year-end 2000. The explanatory variables in our base regressions include POLITY, LOWCAP, GDPCAP, SCHOOL, and POP65. The results are presented in Table 3.

We find that our political-institutional variable, POLITY, has little power in explaining variation in COVGDP. Most of the variation in COVGDP is explained by the 
variable LOWCAP, our measure of the share of risky banks in the system. We find that coverage is higher (as measured by COVGDP) in countries where banks with relatively low capital-to-asset ratios constitute a larger share of the banking system. This result is consistent with the private interest view.

We also find that coverage is lower in countries with higher secondary school enrollment rates, as measured by the variable SCHOOL. However, this effect loses statistical significance once we control for POP65, the share of the population with age 65 and above. We do not find that our proxy for the general level of economic development, GDPCAP, is significantly associated with the size of coverage, and the significance of LOWCAP is not affected once we control for the level of per capita GDP in the country.

For robustness, we consider several alternative and additional explanatory variables. First, we use more specific measures of the political arrangements in the countries in our sample. These include the Polity sub-indexes DEMOC and AUTOC, the Polity measure of executive constraints XCONST, and the indicator COALITION. The results of using these alternative measures of political arrangements in the country are presented in columns 1 to 4 of Table 4 . In addition to these political variables, we also control for LOWCAP and SCHOOL, the two variables with most explanatory power in the regressions presented in Table 3. Again, we find that the political-institutional variables have little power in explaining variation in COVGDP. While we find that coverage levels are lower in countries with more democratic (less autocratic) governments, in countries that place more constraints on the executive, and in countries 
with coalition governments, none of these alternative political variables is significant from a statistical point of view.

As a second robustness test, we include alternative measures of the relative size of risky banking assets in the country. These include the variables NPLAST and SMLBNK. The results are presented in columns 5 and 6 of Table 4 . While we find that coverage levels are significantly higher in countries where banks have a larger proportion of nonperforming loans, which is consistent with private interest theory, we do not find that the level of coverage limits is significantly affected by the share of small banks in the banking system, as measured by the variable SMLBNK. Under the presumption that smaller banks tend to be riskier than large banks, private interest theory would predict that deposit insurance limits are higher in countries where the political influence of the smaller, riskier banks relative to that of the larger, safer banks is greater, and would thus predict a positive relationship between COVGDP and SMLBNK. To the extent that small banks are riskier and less efficient than large banks, a negative relationship between COVGDP and SMLBNK is consistent with public interest theory because the social costs of deposit insurance are likely to be higher in countries where the size of the riskier and smaller banks is relatively larger. While previous research on the U.S. banking system (including Kroszner and Strahan, 2001) has used bank size as a proxy for bank risk, our results suggest that bank size is not necessarily a good proxy for bank risk in other countries around the world. Our other proxies for bank risk, LOWCAP and NPLAST, provide statistically significant evidence in support of a positive association between coverage limits and the share of risky banks, which is consistent with the private interest view. 
Next, we use adult literacy rates as an alternative measure of the country's education level. The regression results that we obtain when controlling for LITERACY are reported in column 7 of Table 4 . We find a significantly negative association between literacy rates and the level of coverage limits, which is consistent with the results obtained when using secondary school enrollment rates as a measure of education levels in the country. These results suggest that coverage is more limited in countries with better educated depositors. Note that the number of countries drops to 33 because we do not have information on literacy rates for many countries (including all developed countries) in our sample. ${ }^{7}$

We also consider restrictions on insurance activities. The results obtained when adding RESTRICT to the regression specification are presented in column 8 of Table 4 . We find that the presence of more restrictions on insurance activities is positively related to the size of deposit insurance coverage, although the effect is not statistically significant. This result is consistent with private interest theory, which predicts that opposition against high coverage limits is greater in countries where banks can sell insurance products. On the other hand, if it is in the public interest to protect the franchise value of banks from competing industries, then high coverage limits of deposit insurance are more likely when there are no activity restrictions. Public interest theory, therefore, predicts that the presence of restrictions on insurance activities is negatively correlated with the size of deposit insurance coverage.

\footnotetext{
${ }^{7}$ In a robustness test, we assume literacy rates of 100 percent for all developed countries. The results do not change.
} 
Next, we control for financial structure using the variable STRUCTURE. The results are presented in column 9 of Table 4 . We do not find that having a market- or bank-based system significantly affects the size of deposit insurance coverage.

Finally, we control for the level of property rights in the country. Column 10 in Table 4 shows the results when controlling for PROPERTY. The variable PROPERTY proxies for the protection of property rights in the country and more generally for the country's contracting environment. Since the moral hazard problems associated with deposit insurance are likely to be exacerbated in countries with poor protection of property rights, public interest theory would predict a negative relationship between the protection of property and the size of deposit insurance coverage. However, we find that coverage limits are higher in countries with better protection of property rights, although the effect is not statistically significant (note that a lower score of the property rights index indicates greater protection of property). This result is more consistent with private interest theory, which predicts that the constituents representing weak banks in countries with poor contracting environments are more likely to lobby for high levels of deposit insurance coverage. Overall, we find that coverage levels are best explained by measures of relative bank risk (LOWCAP) and education levels (SCHOOL).

As an additional robustness test, we use COVDEP as alternative dependent variable instead of COVGDP. The regression results using COVDEP as dependent variable are reported in Table 5. Our results do not change, which is not surprising, given that the average deposit per capita is highly correlated with per capita GDP. Again, we find that coverage is greater in countries that have a larger share of banks with relatively low capital-to-asset ratios and in countries with lower secondary school enrollment rates. 
Political variables (POLITY, DEMOC, and AUTOC) do not have additional power in explaining variation in the size of coverage beyond the effect of our proxies for bank risk and education levels. Per capita income also does not enter significantly once we control for LOWCAP and SCHOOL.

We are also concerned about the possibility that sample selection could affect our results. The European Union (EU) directive on deposit insurance of 1994 imposes minimum standards on national deposit insurance policies in the 15 EU countries, including a minimum covered amount of $€ 20,000$ per individual. As a result, many EU countries have set their coverage limit at the required minimum of $€ 20,000$ (although the official level exceeds the prescribed minimum in a number of EU countries, such as France and Italy). In a robustness test, we therefore exclude the $15 \mathrm{EU}$ countries from the sample. The results are presented in column 1 of Table 6 . The explanatory variables include our main political variable, POLITY, and the two variables that have thus far shown to explain most of the variation in the size of deposit insurance coverage, LOWCAP and SCHOOL. The dependent variable is again COVGDP. The results are similar, although the schooling rate variable loses significance. The LOWCAP variable, however, remains strongly statistically significant. The effect of LOWCAP on COVGDP is also significant from an economic point of view. The coefficient estimates in column 1 of Table 6 suggest that a one standard deviation reduction in LOWCAP would lead to a decrease in COVGDP of about 0.71 (other things equal). Compared to an average value for COVGDP of 2.60, this is a large decrease (of about 27\%).

The EU-accession countries of Central and Eastern Europe have also been pressed to adopt deposit insurance and raise their coverage levels to a minimum of $€ 20,000$ in 
preparation for full membership in the EU. While most EU-accession countries are increasing their coverage levels gradually and have not yet reached the level of $€ 20,000$, the drive to comply with EU standards is clearly an external factor affecting the coverage levels in these countries, which could potentially bias our results. We therefore check the robustness of our results by excluding the EU-accession countries. The results of this robustness test are presented in column 2 of Table 6 . Our results are not affected. Again, we find that COVGDP is positively associated with LOWCAP and negatively associated with SCHOOL. ${ }^{8}$

Recently, many countries have adopted deposit insurance because they were advised to do so by international financial institutions, such as the International Monetary Fund (IMF). The IMF view culminated in the issuance of a set of guidelines on the development of deposit insurance in 1999 (Garcia, 2000). We therefore check how the results are affected when we exclude those countries that adopted deposit insurance in 1999 or later. ${ }^{9}$ We use the year 1999 to construct this exclusion rule because this is the year that the IMF issued its set of guidelines on developing a deposit insurance system. The results are presented in column 3 of Table 6 . Our results are qualitatively similar. Coverage is higher in countries where banks with relatively low capital-to-asset ratios hold a larger share of banking assets and in countries with low school enrollment rates. We get similar results when excluding countries that adopted deposit insurance after 1995 (not reported).

\footnotetext{
${ }^{8}$ The results are similar when we exclude both EU and EU-accession countries.

${ }^{9}$ Another reason for excluding recent adopters is that these countries may not have reached their desired level of deposit insurance coverage because coverage limits and deposit insurance fund assets are often built-up slowly during the first years following the introduction of deposit insurance. Also, recent adoption of explicit deposit insurance may suggest that the majority of constituencies in the country have opposed deposit insurance for many years.
} 
On the other hand, the current coverage levels of early adopters may not reflect the desired level of coverage. While countries do regularly amend their deposit insurance laws to update coverage levels, not all countries have done so in recent years. The complexity of the political and legal issues underlying financial reform often slows down the reform process, and countries generally tend to be reluctant to frequently amend laws. As a result, coverage levels are often adjusted only slowly over time. Therefore, we check the robustness of our results to excluding countries that adopted deposit insurance before 1990 (i.e., ten years before the end of our sample period). This rule excludes 26 countries or about half of our sample of countries. By excluding these early adopters, we align more closely our explanatory variables with the deposit insurance adoption. The results are presented in column 4 of Table 6 . Our results are qualitatively similar, despite the fact that we drop a large number of countries.

A related concern is that current coverage levels are in part determined by country circumstances at the time of deposit insurance adoption. This could render our crosssectional analysis invalid. Unfortunately, we do not have data on all control variables at the time of adoption and we therefore cannot perform a panel data analysis. However, since countries regularly amend their deposit insurance laws to update coverage levels, we do not think this is a major problem. Also, this potential problem is likely to be greatest for countries that adopted deposit insurance many years ago, but the regression results reported in column 4 of Table 6 show that our results are not affected when we exclude early adopters.

Many countries have adopted deposit insurance during episodes of systemic financial distress, when there is a loss of public confidence in the banking system 
(Demirgüç-Kunt and Detragiache, 2002). One would expect deposit insurance coverage levels to be higher during periods of financial distress, because of the government's desire to stem the financial crisis and restore public confidence. Coverage levels during crisis episodes, therefore, may reflect more the political shift towards increased support for deposit insurance rather than political-institutional or other country characteristics. ${ }^{10}$

Because coverage levels are likely to be different during periods of systemic financial distress, we exclude in a robustness test countries that are experiencing a banking crisis. ${ }^{11}$ We use data on the timing of systemic banking crises from Caprio and Klingebiel (2002) to identify whether the country is experiencing a banking crisis or not. In column 5 of Table 6 , we report the results obtained when excluding countries that experienced a banking crisis during the year 2000. The results do not change qualitatively. The results are also not affected when we exclude countries that experienced a systemic banking crisis during the last 3 years (column 6 of Table 6).

Finally, we are concerned that our results may be biased because actual coverage levels are only observed for countries with explicit deposit insurance. We employ a Heckman model to control for this potential sample selection problem. The dependent variable in the first-stage selection model is DI, a dummy variable that takes a value of one if the country has adopted deposit insurance, and zero otherwise. The dependent variable in the second-stage regression is COVGDP, the ratio of the coverage limit per

\footnotetext{
${ }^{10}$ Indeed, the U.S. experience of the 1930s shows that policymakers can become more favorable to the adoption of deposit insurance in the wake of a financial crisis. While deposit insurance is often adopted during financial crisis in the public interest of restoring confidence in the banking system, private interests are generally at play as well and are likely to affect the deposit insurance adoption process. The work by Calomiris and White (1994) supports this view by arguing that deposit insurance in the United States was instituted during the Great Depression not only to restore public confidence, but also for the benefit of the smaller and riskier banks that were lobbying for deposit insurance.

${ }^{11}$ Our analysis also excludes countries with government blanket guarantees on deposits from the sample.
} 
depositor to the level of per capita GDP. The results are presented in Table 7. We exclude countries with full government guarantees on deposits from the sample.

Our results do not change qualitatively, although the statistical significance of LOWCAP drops somewhat. The first-step results show that countries with a higher POLITY score are somewhat more likely to adopt deposit insurance. Countries with explicit deposit insurance also tend to have higher values of LOWCAP. Overall, the results suggest that there is no significant sample selection bias.

\section{Conclusions}

We use a political economy framework to empirically analyze cross-country differences in deposit insurance coverage. We find that deposit insurance coverage is higher in countries where poorly capitalized banks dominate the market and in countries where the average education level of depositors is lower. We do not find that coverage is significantly related to political-institutional variables, such as the degree of democracy or restraints on the executive, or to proxies for the general level of institutional development, such as per capita income or property rights. These results provide evidence in support of the private interest view, according to which risky banks lobby for extensive coverage. Although it is not always straightforward to differentiate between public and private interest theory, these results suggest that cross-country differences in deposit insurance coverage are best explained by private interest theory.

This conclusion is similar to Kroszner and Strahan (2001), who study deposit insurance limits in the U.S. banking system and find support mainly for the private interest view. They use the relative importance of small banks as a proxy for the risk of 
the banking system because in the United States small banks tend to be riskier than large banks. Using bank size as a measure of bank risk, they find that the size of deposit insurance coverage is positively correlated with the share of risky banks. We obtain similar results when using capital-to-asset ratios and nonperforming loan ratios as proxies for bank risk. We do not find a significant relationship between bank size and deposit insurance coverage, suggesting that bank size may not be a good proxy for bank risk in countries other than the United States. This could be because the largest banks in many countries are often state-owned and inefficient and have risky loan portfolios (La Porta, Lopez-de-Silanes, and Shleifer, 2002).

Although governments often claim that they introduce deposit insurance in the interest of the public at large and to protect small depositors, our results suggest that politicians are influenced by political constituencies with private interests and need not act in the public interest. As a result, deposit insurance need not always be a social welfare maximizing proposition.

We have shown how interest group theory can be applied to the area of deposit insurance design. In future work, we plan to use a similar approach to analyze why some countries adopt explicit deposit insurance and others do not. To date, the lack of longitudinal data on political-institutional and banking structure variables render such analysis impossible. 


\section{References}

Alesina, A., and G. Tabellini. "A Positive Theory of Fiscal Deficits and Government Debt." Review of Economic Studies 57 (1990), 403-414.

Barro, R. J., and D. B. Gordon. "A Positive Theory of Monetary Policy in a Natural Rate Model." Journal of Political Economy 91 (1983), 589-610.

Barth, J. R., G. Caprio, and R. Levine. "Bank Regulation and Supervision: What Works Best?" Journal of Financial Intermediation (2004), forthcoming.

Beck, T., G. Clarke, A. Groff, P. Keefer, and P. Walsh. "New Tools in Comparative Political Economy: The Database of Political Institutions." World Bank Economic Review 15 (2001), 165-176.

Becker, G. S. "A Theory of Competition among Pressure Groups for Political Influence.” Quarterly Journal of Economics 98 (1983), 371-400.

Bolton, P., and H. Rosenthal. "Political Intervention in Debt Contracts." Journal of Political Economy 110 (2002), 1103-1134.

Calomiris, C., and E. White. "The Origins of Federal Deposit Insurance," In: C. Goldin and G. Libecap, eds., The Regulated Economy: A Historical Approach to Political Economy. Chicago: University of Chicago Press, 1994, pp. 145-188.

Caprio, G., and D. Klingebiel. "Episodes of Systemic and Borderline Financial Crises." World Bank: Mimeo (2002).

Demirgüç-Kunt, A., and E. Detragiache. "Does Deposit Insurance Increase Banking System Stability? An Empirical Investigation." Journal of Monetary Economics 49 (2002), 1373-1406. 
Demirgüç-Kunt, A., and E. Kane. "Deposit Insurance Around the World: Where Does it Work?” Journal of Economic Perspectives 16 (2002), 175-195.

Demirgüç-Kunt, A., and T. Sobaci. “A New Development Database. Deposit Insurance around the World.” World Bank Economic Review 15 (2001), 481-490.

Diamond, D., and P. Dybvig. “Bank Runs, Deposit Insurance and Liquidity.” Journal of Political Economy 91 (1983), 401-419.

Economides, N., R. G. Hubbard, and D. Palia. "The Political Economy of Branching Restrictions and Deposit Insurance.” Journal of Law and Economics 29 (1996), 667-704.

Garcia, G. G. "Deposit Insurance: Actual and Good Practices.” Occasional Paper No. 197, International Monetary Fund, 2000.

Giammarino, R., E. Schwartz, and J. Zechner. "Market Valuation of Banks Assets and Deposit Insurance in Canada." Canadian Journal of Economics 22 (1989), 109127.

Grossman, G., and E. Helpman. "The Politics of Free-Trade Agreements." American Economic Review 85 (1995), 667-690.

Grossman, G., and E. Helpman. Special Interest Politics. Cambridge MA: MIT Press, 2001.

Hovakimian, A., E. Kane, and L. Laeven. "How Country and Safety-Net Characteristics Affect Bank Risk-Shifting.” Journal of Financial Services Research 23 (2003), 177-204.

Joskow, P. L., and R. G. Noll. "Regulation in Theory and Practice: An Overview.” In: G. Fromm, ed., Studies in Public Regulation. Cambridge: MIT Press, 1981, pp. 1-65. 
Kane, E. J. "De Jure Interstate Banking: Why Only Now?" Journal of Money, Credit, and Banking 28 (1996), 141-161.

Kane, E. J., and B. K. Wilson. "A Contracting-Theory Interpretation of the Origins of Federal Deposit Insurance.” Journal of Money, Credit, and Banking 30 (1998), 573-595.

Kroszner, R. "The Political Economy of Banking and Financial Regulatory Reform in Emerging Markets." Research in Financial Services 10 (1998), 33-51.

Kroszner, R., and P. Strahan. "What Drives Deregulation? Economics and Politics of the Relaxation of Bank Branching Restrictions.” Quarterly Journal of Economics 114 (1999), 1437-1467.

Kroszner, R., and P. Strahan. "Obstacles to Optimal Policy: The Interplay of Politics and Economics in Shaping Bank Supervision and Regulation Reforms.” In: F. S. Mishkin, ed., Prudential Supervision: What Works and What Doesn't. Chicago: University of Chicago Press, 2001, pp. 233-273.

Kroszner, R., and T. Stratmann. "Interest Group Competition and the Organization of Congress: Theory and Evidence from Financial Services' Political Action Committees.” American Economic Review 88 (1998), 1163-1187.

Krueger, A. O. "The Political Economy of the Rent-Seeking Society." American Economic Review 64 (1974), 291-303.

La Porta, R., F. Lopez-de-Silanes, A. Shleifer, and R. Vishny. "The Quality of Government." Journal of Law, Economics and Organization 15 (1999), 222-279.

La Porta, R., F. Lopez-de-Silanes, and A. Shleifer. "Government Ownership of Banks." Journal of Finance 57 (2002), 265-301. 
Laeven, L. "Bank Risk and Deposit Insurance." World Bank Economic Review 16 (2002a), 109-137.

Laeven, L. "Pricing of Deposit Insurance." Policy Research Working Paper No. 2871, World Bank, 2002b.

Levine, R. "Bank-Based or Market-Based Financial Systems: Which is Better?" Journal of Financial Intermediation 11 (2001), 1-30.

Mulligan, C. B., and X. Sala-i-Martin. "Gerontocracy, Retirement, and Social Security." NBER Working Paper 7117, 1999.

Mulligan, C. B., R. Gil, and X. Sala-i-Martin. "Social Security and Democracy." NBER Working Paper 8958, 2002.

Merton, R. "An Analytical Derivation of the Cost of Deposit Insurance and Loan Guarantees.” Journal of Banking and Finance 1 (1977), 3-11.

North, D. C. "A Transactions Cost Theory of Politics." Journal of Theoretical Politics 2 (1990), 355-367.

Pagano, M., and P. Volpin. "The Political Economy of Finance." Oxford Review of Economic Policy 17 (2001a), 502-519.

Pagano, M., and P. Volpin. "The Political Economy of Corporate Governance." American Economic Review, Forthcoming.

Peltzman, S. "Toward a More General Theory of Regulation." Journal of Law and Economics 19 (1976), 109-148.

Perotti, E., and P. Volpin. "The Political Economy of Entry: Lobbying, Inequality and Financial Development." University of Amsterdam, Mimeo, 2003. 
Persson, T., and G. Tabellini. Political Economics - Explaining Economic Policy. Cambridge: MIT Press, 2000.

Poole, K. T., and H. Rosenthal. Congress: A Political-Economic History of Roll Call Voting. Oxford: Oxford University Press, 1997.

Ronn, E. I., and A. K. Verma. "Pricing Risk-Adjusted Deposit Insurance: An OptionBased Model." Journal of Finance 41 (1986), 871-895.

Stigler, G. J. "The Theory of Economic Regulation." Bell Journal of Economics and Management Science 2 (1971), 3-21.

White, E. "State-Sponsored Insurance of Bank Deposits in the United States 1907-1929." Journal of Economic History 41 (1981), 537-557.

White, E. "The Legacy of Deposit Insurance: The Growth, Spread and Cost of Insuring Financial Intermediaries.” In: M. Bordo, C. Goldin, and E. White, eds., The Defining Moment: The Great Depression and the American Economy in the Twentieth Century. Chicago: Chicago University Press, 1998. 


\section{Table 1: Overview of Deposit Insurance Systems Around the World}

This table indicates whether the country has an explicit or implicit deposit insurance system. In total, data is available for 111 countries. Data as of end-2000. Of the 69 countries with explicit deposit insurance listed here, 7 countries had explicit full government guarantees on deposits in place at end-2000: Chile (only on time deposits), Ecuador, Japan, Republic of Korea, Mexico, Turkey, and Turkmenistan.

\begin{tabular}{|l|l|}
\hline $\begin{array}{l}\text { Explicit deposit insurance } \\
\text { (69 countries) }\end{array}$ & Argentina, Austria, Bahamas, Bahrain, Bangladesh, Belarus, Belgium, \\
& Bosnia and Herzegovina, Brazil, Bulgaria, Canada, Chile, Colombia, \\
& Croatia, Cyprus, Czech Republic, Denmark, Dominican Republic, Ecuador, \\
& El Salvador, Estonia, Finland, France, Germany, Greece, Guatemala, \\
& Honduras, Hungary, Iceland, India, Ireland, Italy, Jamaica, Japan, \\
& Kazakhstan, Kenya, Republic of Korea, Latvia, Lebanon, Lithuania, \\
& Luxembourg, FYR of Macedonia, Mexico, Morocco, Netherlands, Nigeria, \\
& Norway, Oman, Peru, Philippines, Poland, Portugal, Romania, Slovak \\
& Republic, Spain, Sri Lanka, Sweden, Switzerland, Taiwan (China), \\
& Tanzania, Trinidad and Tobago, Turkey, Turkmenistan, Uganda, Ukraine, \\
& United Kingdom, United States, Venezuela, and Vietnam \\
\hline Implicit deposit insurance & Albania, Armenia, Australia, Azerbaijan, Bhutan, Bolivia, Botswana, \\
& Burundi, Cambodia, China, Costa Rica, Egypt, Arab Rep., Gambia, \\
& Georgia, Ghana, Guyana, Hong Kong (China), Indonesia, Israel, Jordan, \\
& Kuwait, Kyrgyz Republic, Lesotho, Malawi, Malaysia, Malta, Mauritius, \\
& Moldova, Namibia, Nepal, New Zealand, Pakistan, Panama, Qatar, Russian \\
& Federation, Rwanda, Saudi Arabia, Singapore, Slovenia, South Africa, \\
& Thailand, and Zambia \\
\hline
\end{tabular}




\section{Table 2: Summary Statistics of the Main Variables}

This table reports summary statistics for the main variables for the sample of countries with explicit deposit insurance. COVGDP is the ratio of coverage limit per deposit to GDP per capita at year-end 2000. COVDEP is the ratio of coverage limit per deposit to total deposits per capita at year-end 2000. POLITY is the average for the years 1990-99 of the Polity IV composite index. DEMOC is the average for the years 1990-99 of the Polity IV democracy index. AUTOC is the average for the years 1990-99 of the Polity IV autocracy index. XCONST is the average for the years 1990-99 of the Polity IV executive constraints index. COALITION is the average for the years 1975-97 of a dummy variable that takes value of one if the government of the country is a coalition government, and zero otherwise. LOWCAP is the percentage of banking assets in the country in banks with capital-asset ratios below the median size in the country. NPLAST is the ratio of nonperforming loans to total assets. SMLBNK is the percentage of banking assets in the country in small banks, where banks are defined as small if they have assets below the median size in each country. SCHOOL is the secondary school enrollment rate. LITERACY is the adult literacy rate. POP65 is the share of the population with age 65 and above in the total adult population (age 15 and above) in the country. RESTRICT is a country-level measure of the degree to which banks are restricted to sell insurance, and ranges from 0 to 3 , with a higher score indicating more restrictions. STRUCTURE is a measure of financial system structure for the years 1985-99. A higher score indicates a more market-based system, and a lower score indicates a more bank-based system. PROPERTY is an index of property rights in the country for the year 1999. GDPCAP is average per capita income over the period 1995-1999 in 1995 US dollars. A more detailed definition of the variables and the sources of the data can be found in section 3 .

\begin{tabular}{lrrrrr}
\hline Variable & $\begin{array}{r}\text { Number of } \\
\text { observations }\end{array}$ & Mean & $\begin{array}{r}\text { Standard } \\
\text { deviation }\end{array}$ & Minimum & Maximum \\
\hline COVGDP & 61 & 2.60 & 2.03 & 0.30 & 9.10 \\
COVDEP & 61 & 8.95 & 11.05 & 0.15 & 68.70 \\
POLITY & 56 & 6.06 & 5.40 & -9.09 & 10.00 \\
DEMOC & 56 & 7.13 & 3.36 & 0.00 & 10.00 \\
AUTOC & 56 & 1.07 & 2.18 & 0.00 & 9.09 \\
XCONST & 56 & 5.68 & 1.64 & 1.80 & 7.00 \\
COALITION & 60 & 0.26 & 0.39 & 0.00 & 1.00 \\
LOWCAP & 60 & 71.76 & 20.20 & 7.67 & 98.08 \\
NPLAST & 44 & 9.19 & 11.55 & 0.10 & 44.00 \\
SMLBNK & 60 & 8.76 & 6.22 & 0.76 & 26.73 \\
SCHOOL & 55 & 86.30 & 28.93 & 26.06 & 149.38 \\
LITERACY & 34 & 86.90 & 16.36 & 39.74 & 99.80 \\
POP65 & 55 & 13.55 & 5.25 & 4.50 & 21.41 \\
RESTRICT & 54 & 1.56 & 0.95 & 0.00 & 3.00 \\
STRUCTURE & 52 & -0.50 & 0.88 & -3.59 & 0.84 \\
PROPERTY & 60 & 2.32 & 1.11 & 1.00 & 5.00 \\
GDPCAP & 61 & $12,065.43$ & $14,250.36$ & 190.49 & $56,372.00$ \\
\hline
\end{tabular}




\section{Table 3: Determinants of deposit insurance coverage}

Dependent variable is COVGDP, which is the ratio of coverage limit per deposit to per capita GDP at yearend 2000. Regressions are estimated using OLS with robust standard errors. POLITY is the average for the years 1990-99 of the Polity IV composite index. LOWCAP is the percentage of banking assets in the country in banks with capital-asset ratios below the median size in the country. SCHOOL is the secondary school enrollment rate. POP65 is the share of the population with age 65 and above in the total adult population (age 15 and above) in the country. GDPCAP is the logarithm of the average per capita income over the period 1995-1999 in 1995 U.S. dollars. A more detailed definition of the variables and the sources of the data can be found in section 3. Heteroskedasticity-consistent standard errors are reported between brackets. ${ }^{*}, * *$, and $* * *$ indicate statistical significance at $10 \%, 5 \%$, respectively $1 \%$.

\begin{tabular}{lllllll}
\hline & $(1)$ & $(2)$ & $(3)$ & $(4)$ & $(5)$ & $(6)$ \\
\hline POLITY & $-0.112^{* *}$ & -0.081 & -0.051 & -0.041 & -0.056 & -0.066 \\
& $(0.048)$ & $(0.066)$ & $(0.060)$ & $(0.054)$ & $(0.050)$ & $(0.056)$ \\
LOWCAP & $0.017^{*}$ & $0.020^{* *}$ & $0.028^{* * *}$ & $0.028^{* * *}$ & $0.026^{* * *}$ & $0.027^{* * *}$ \\
& $(0.010)$ & $(0.009)$ & $(0.008)$ & $(0.009)$ & $(0.008)$ & $(0.008)$ \\
GDPCAP & & -0.191 & & & 0.270 & 0.253 \\
& & $(0.258)$ & & & $(0.273)$ & $(0.279)$ \\
SCHOOL & & & $-0.027^{* *}$ & -0.018 & -0.026 & $-0.035^{* *}$ \\
& & & $(0.011)$ & $(0.019)$ & $(0.022)$ & $(0.014)$ \\
POP65 & & & & -0.065 & -0.071 & \\
& & & & $(0.104)$ & $(0.101)$ & \\
Constant & $2.107^{* * *}$ & 3.303 & $3.201^{* * *}$ & $3.294^{* * *}$ & 1.998 & 1.976 \\
& $(0.752)$ & $(1.998)$ & $(0.966)$ & $(1.039)$ & $(1.834)$ & $(1.831)$ \\
& & & & & & \\
Observations & 55 & 55 & 51 & 51 & 51 & 51 \\
R-squared & 0.11 & 0.12 & 0.26 & 0.26 & 0.28 & 0.27 \\
\hline
\end{tabular}




\section{Table 4: Determinants of deposit insurance coverage: Alternative explanatory variables}

Dependent variable is COVGDP, which is the ratio of coverage limit per deposit to per capita GDP at yearend 2000. Regressions are estimated using OLS with robust standard errors. DEMOC is the average for the years 1990-99 of the Polity IV democracy index. AUTOC is the average for the years 1990-99 of the Polity IV autocracy index. XCONST is the average for the years 1990-99 of the Polity IV executive constraints index. COALITION is the average for the years 1975-97 of a dummy variable that takes value of one if the government of the country is a coalition government, and zero otherwise. POLITY is the average for the years 1990-99 of the Polity IV composite index. LOWCAP is the percentage of banking assets in the country in banks with capital-asset ratios below the median size in the country. NPLAST is the ratio of nonperforming loans to total assets. SMLBNK is the percentage of banking assets in the country in small banks, where banks are defined as small if they have assets below the median size in each country. SCHOOL is the secondary school enrollment rate. LITERACY is the adult literacy rate. POP65 is the share of the population with age 65 and above in the total adult population (age 15 and above) in the country. RESTRICT is a country-level measure of the degree to which banks are restricted to sell insurance, and ranges from 0 to 3, with a higher score indicating more restrictions. STRUCTURE is a measure of financial system structure. A higher score indicates a more market-based system., and a lower score indicates a more bank-based system. PROPERTY is an index of property rights in the country for the year 1999. GDPCAP is the logarithm of the average per capita income over the period 1995-1999 in 1995 U.S. dollars. A more detailed definition of the variables and the sources of the data can be found in section 3. Heteroskedasticityconsistent standard errors are reported between brackets. ${ }^{*}, * *$, and $* * *$ indicate statistical significance at $10 \%, 5 \%$, respectively $1 \%$.

\begin{tabular}{|c|c|c|c|c|c|c|c|c|c|c|}
\hline & (1) & (2) & (3) & (4) & $(5)$ & (6) & (7) & (8) & (9) & (10) \\
\hline DEMOC & $\begin{array}{l}-0.078 \\
(0.108)\end{array}$ & & & & & & & & & \\
\hline AUTOC & & $\begin{array}{l}0.123 \\
(0.125)\end{array}$ & & & & & & & & \\
\hline XCONST & & & $\begin{array}{l}-0.112 \\
(0.255)\end{array}$ & & & & & & & \\
\hline COALITION & & & & $\begin{array}{l}-0.361 \\
(0.610)\end{array}$ & & & & & & \\
\hline POLITY & & & & & $\begin{array}{l}-0.086 \\
(0.073)\end{array}$ & $\begin{array}{l}-0.070 \\
(0.064)\end{array}$ & $\begin{array}{l}-0.067 \\
(0.048)\end{array}$ & $\begin{array}{l}-0.041 \\
(0.056)\end{array}$ & $\begin{array}{l}-0.045 \\
(0.073)\end{array}$ & $\begin{array}{l}-0.075 \\
(0.067)\end{array}$ \\
\hline LOWCAP & $\begin{array}{l}0.029 * * * \\
(0.008)\end{array}$ & $\begin{array}{l}0.028 * * * \\
(0.008)\end{array}$ & $\begin{array}{l}0.028 * * * \\
(0.009)\end{array}$ & $\begin{array}{l}0.030^{* * * *} \\
(0.008)\end{array}$ & & & $\begin{array}{l}0.040 * * * \\
(0.009)\end{array}$ & $\begin{array}{l}0.028^{* * * *} \\
(0.006)\end{array}$ & $\begin{array}{l}0.027 * * * \\
(0.009)\end{array}$ & $\begin{array}{l}0.027 * * * \\
(0.008)\end{array}$ \\
\hline NPLAST & & & & & $\begin{array}{l}0.052^{*} \\
(0.026)\end{array}$ & & & & & \\
\hline SMLBNK & & & & & & $\begin{array}{l}-0.053 \\
(0.044)\end{array}$ & & & & \\
\hline SCHOOL & $\begin{array}{l}-0.027^{* *} \\
(0.011)\end{array}$ & $\begin{array}{l}-0.028 * * * \\
(0.010)\end{array}$ & $\begin{array}{l}-0.028^{* *} \\
(0.011)\end{array}$ & $\begin{array}{l}-0.030^{* * *} \\
(0.009)\end{array}$ & $\begin{array}{l}-0.005 \\
(0.011)\end{array}$ & $\begin{array}{l}-0.027^{* *} \\
(0.012)\end{array}$ & & $\begin{array}{l}-0.026^{* *} \\
(0.011)\end{array}$ & $\begin{array}{l}-0.027^{* *} \\
(0.012)\end{array}$ & $\begin{array}{l}-0.030^{* *} \\
(0.012)\end{array}$ \\
\hline LITERACY & & & & & & & $\begin{array}{l}-0.039 * * \\
(0.016)\end{array}$ & & & \\
\hline RESTRICT & & & & & & & & $\begin{array}{l}0.449 \\
(0.287)\end{array}$ & & \\
\hline STRUCTURE & & & & & & & & & $\begin{array}{l}0.011 \\
(0.305)\end{array}$ & \\
\hline PROPERTY & & & & & & & & & & $\begin{array}{l}-0.296 \\
(0.319)\end{array}$ \\
\hline Constant & $\begin{array}{l}3.414 * * * \\
(1.014)\end{array}$ & $\begin{array}{l}2.874 * * \\
(1.078)\end{array}$ & $\begin{array}{l}3.688^{* *} \\
(1.530)\end{array}$ & $\begin{array}{l}3.017 * * * \\
(0.946)\end{array}$ & $\begin{array}{l}3.020^{* * * *} \\
(0.928)\end{array}$ & $\begin{array}{l}5.773 * * * \\
(1.170)\end{array}$ & $\begin{array}{l}3.983 * * \\
(1.577)\end{array}$ & $\begin{array}{l}2.304 \\
(1.420)\end{array}$ & $\begin{array}{l}3.238^{* * *} \\
(1.118)\end{array}$ & $\begin{array}{l}4.419 * * * \\
(1.622)\end{array}$ \\
\hline Observations & 51 & 51 & 51 & 54 & 39 & 51 & 33 & 48 & 49 & 50 \\
\hline R-squared & 0.25 & 0.26 & 0.25 & 0.25 & 0.26 & 0.19 & 0.34 & 0.36 & 0.23 & 0.26 \\
\hline
\end{tabular}




\section{Table 5: Determinants of deposit insurance coverage: Alternative dependent variable}

Dependent variable is COVDEP, which is the ratio of coverage limit per deposit to total deposits per capita at year-end 2000. Regressions are estimated using OLS with robust standard errors. POLITY is the average for the years 1990-99 of the Polity IV composite index. DEMOC is the average for the years 1990-99 of the Polity IV democracy index. AUTOC is the average for the years 1990-99 of the Polity IV autocracy index. LOWCAP is the percentage of banking assets in the country in banks with capital-asset ratios below the median size in the country. SCHOOL is the secondary school enrollment rate. GDPCAP is the logarithm of the average per capita income over the period 1995-1999 in 1995 U.S. dollars. A more detailed definition of the variables and the sources of the data can be found in section 3. Heteroskedasticity-consistent standard errors are reported between brackets. *,**, and *** indicate statistical significance at 10\%, 5\%, respectively $1 \%$.

\begin{tabular}{lllll}
\hline & $(1)$ & $(2)$ & $(3)$ & $(4)$ \\
\hline POLITY & -0.335 & -0.294 & & \\
& $(0.227)$ & $(0.262)$ & & \\
DEMOC & & & -0.679 & \\
& & & $(0.408)$ & 0.535 \\
AUTOC & & & $(0.525)$ \\
LOWCAP & $0.090^{* *}$ & $0.095 * *$ & $0.090^{* *}$ & $0.092^{* *}$ \\
& $(0.038)$ & $(0.039)$ & $(0.038)$ & $(0.039)$ \\
SCHOOL & $-0.114 * * *$ & $-0.093 * *$ & $-0.100 * * *$ & $-0.131 * * *$ \\
& $(0.034)$ & $(0.039)$ & $(0.035)$ & $(0.033)$ \\
GDPCAP & & -0.679 & & \\
Constant & $13.674 * * *$ & $(1.059)$ & & $12.394 * * *$ \\
& $(3.217)$ & $(6.279)$ & $(3.694)$ & $(3.241)$ \\
Observations & 51 & 51 & 51 & \\
R-squared & 0.32 & 0.32 & 0.33 & 0.30 \\
\hline
\end{tabular}




\section{Table 6: Determinants of deposit insurance coverage: Sample selection}

Dependent variable is COVGDP, which is the ratio of coverage limit per deposit to per capita GDP at yearend 2000. Regressions are estimated using OLS with robust standard errors. POLITY is the average for the years 1990-99 of the Polity IV composite index. LOWCAP is the percentage of banking assets in the country in banks with capital-asset ratios below the median size in the country. SCHOOL is the secondary school enrollment rate. A more detailed definition of the variables and the sources of the data can be found in section 3. Column (1) excludes EU-15 countries. Column (2) excludes EU-accession countries. Column (3) excludes recent adopters (adoption within last 2 years). Column (4) excludes early adopters (adoption before 1990). Column (5) excludes countries that experienced a banking crisis during the year 2000. Column (6) excludes countries that experienced a banking crisis during the period 1997-2000. Heteroskedasticity-consistent standard errors are reported between brackets. *, **, and *** indicate statistical significance at $10 \%, 5 \%$, respectively $1 \%$.

\begin{tabular}{lllllll}
\hline & $(1)$ & $(2)$ & $(3)$ & $(4)$ & $(5)$ & $(6)$ \\
\hline POLITY & -0.056 & -0.047 & -0.089 & -0.075 & -0.049 & -0.069 \\
& $(0.064)$ & $(0.064)$ & $(0.069)$ & $(0.066)$ & $(0.069)$ & $(0.067)$ \\
LOWCAP & $0.035^{* * *}$ & $0.025^{* *}$ & $0.027^{* * *}$ & $0.037^{* * *}$ & $0.027^{* * *}$ & $0.033^{* * *}$ \\
& $(0.013)$ & $(0.011)$ & $(0.009)$ & $(0.010)$ & $(0.009)$ & $(0.012)$ \\
SCHOOL & -0.017 & $-0.027^{* *}$ & $-0.021^{* *}$ & $-0.040^{*}$ & $-0.030^{* *}$ & $-0.037^{* *}$ \\
& $(0.020)$ & $(0.012)$ & $(0.010)$ & $(0.022)$ & $(0.013)$ & $(0.014)$ \\
Constant & 2.111 & $3.447^{* * *}$ & $3.068^{* * *}$ & $3.958^{* *}$ & $3.685^{* * *}$ & $4.007^{* * *}$ \\
& $(1.914)$ & $(1.095)$ & $(0.899)$ & $(1.487)$ & $(1.146)$ & $(1.231)$ \\
& & & & & & \\
Observations & 37 & 41 & 46 & 25 & 44 & 40 \\
R-squared & 0.21 & 0.22 & 0.25 & 0.42 & 0.26 & 0.31 \\
\hline
\end{tabular}




\section{Table 7: Heckman model of deposit insurance coverage}

Dependent variable is COVGDP, which is the ratio of coverage limit per deposit to per capita GDP at yearend 2000. Regressions are estimated using a Heckman model, where the dependent variable of the firststage selection model is DI, which is a dummy variable that takes value of one if the country has adopted explicit deposit insurance, and zero if the country has implicit deposit insurance. The independent variables in the selection model are identical to those in the second-stage regression. We exclude countries with full deposit guarantees from the sample. POLITY is the average for the years 1990-99 of the Polity IV composite index. LOWCAP is the percentage of banking assets in the country in banks with capital-asset ratios below the median size in the country. NPLAST is the ratio of nonperforming loans to total assets. SCHOOL is the secondary school enrollment rate. POP65 is the share of the population with age 65 and above in the total adult population (age 15 and above) in the country. GDPCAP is the logarithm of the average per capita income over the period 1995-1999 in 1995 U.S. dollars. A more detailed definition of the variables and the sources of the data can be found in section $3 .{ }^{*}, * *$, and *** indicate statistical significance at $10 \%, 5 \%$, respectively $1 \%$.

\begin{tabular}{|c|c|c|c|}
\hline Second-stage & (1) & (2) & (3) \\
\hline POLITY & $\begin{array}{l}-0.053 \\
(0.073)\end{array}$ & $\begin{array}{l}-0.073 \\
(0.070)\end{array}$ & $\begin{array}{l}-0.089 \\
(0.067)\end{array}$ \\
\hline LOWCAP & $\begin{array}{l}0.028^{*} \\
(0.016)\end{array}$ & $\begin{array}{l}0.025^{*} \\
(0.015)\end{array}$ & \\
\hline NPLAST & & & $\begin{array}{l}0.051^{* *} \\
(0.025)\end{array}$ \\
\hline SCHOOL & $\begin{array}{l}-0.027^{* *} \\
(0.012)\end{array}$ & $\begin{array}{l}-0.035^{* *} \\
(0.014)\end{array}$ & $\begin{array}{l}-0.006 \\
(0.014)\end{array}$ \\
\hline GDPCAP & & $\begin{array}{l}0.241 \\
(0.299)\end{array}$ & \\
\hline Constant & $\begin{array}{l}3.307 \\
(2.482)\end{array}$ & $\begin{array}{l}2.356 \\
(2.800)\end{array}$ & $\begin{array}{l}3.194^{*} \\
(1.782)\end{array}$ \\
\hline First-stage & (1) & (2) & (3) \\
\hline POLITY & $\begin{array}{l}0.052^{*} \\
(0.029)\end{array}$ & $\begin{array}{l}0.050^{*} \\
(0.028)\end{array}$ & $\begin{array}{l}0.043 \\
(0.032)\end{array}$ \\
\hline LOWCAP & $\begin{array}{l}0.014 * * \\
(0.007)\end{array}$ & $\begin{array}{l}0.014^{* *} \\
(0.007)\end{array}$ & \\
\hline NPLAST & & & $\begin{array}{l}0.008 \\
(0.015)\end{array}$ \\
\hline SCHOOL & $\begin{array}{l}0.009 \\
(0.006)\end{array}$ & $\begin{array}{l}0.004 \\
(0.008)\end{array}$ & $\begin{array}{l}0.011 \\
(0.007)\end{array}$ \\
\hline GDPCAP & & $\begin{array}{l}0.143 \\
(0.149)\end{array}$ & \\
\hline Constant & $\begin{array}{l}-1.643 * * * \\
(0.622)\end{array}$ & $\begin{array}{l}-2.335^{* *} \\
(0.961)\end{array}$ & $\begin{array}{l}-0.980^{*} \\
(0.546)\end{array}$ \\
\hline $\begin{array}{l}\text { Censored observations } \\
\text { (implicit deposit insurance) }\end{array}$ & 35 & 35 & 33 \\
\hline $\begin{array}{l}\text { Uncensored observations } \\
\text { (explicit deposit insurance }\end{array}$ & 51 & 51 & 39 \\
\hline Total observations & 86 & 86 & 72 \\
\hline
\end{tabular}




\section{Annex 1: The Data}

This table reports the country-level data for the sample of countries with explicit deposit insurance. COVGDP is the ratio of coverage limit per deposit to GDP per capita at yearend 2000. COVDEP is the ratio of coverage limit per deposit to total deposits per capita at year-end 2000. AGE is 2000 minus the year of inception of explicit deposit insurance. POLITY is the average for the years 1990-99 of the Polity IV composite index. DEMOC is the average for the years 1990-99 of the Polity IV democracy index. AUTOC is the average for the years 1990-99 of the Polity IV autocracy index. XCONST is the average for the years 1990-99 of the Polity IV executive constraints index. COALITION is the average for the years 1975-97 of a dummy variable that takes value of one if the government of the country is a coalition government, and zero otherwise. LOWCAP is the percentage of banking assets in the country in banks with capital-asset ratios below the median size in the country. NPLAST is the ratio of nonperforming loans to total assets. SMLBNK is the percentage of banking assets in the country in banks with assets below the median size in the country. SCHOOL is the secondary school enrollment rate. LITERACY is the adult literacy rate. POP65 is the share of the population with age 65 and above in the total adult population (age 15 and above). RESTRICT is a country-level measure of the degree to which banks are restricted to sell insurance, and ranges from 0 to 3, with a higher score indicating more restrictions. STRUCTURE is a measure of financial system structure for the years 1995-99. PROPERTY is an index of property rights in the country for the year 1999. GDPCAP is average per capita income over the period 1995-1999 in 1995 U.S. dollars. A more detailed definition of the variables and the sources of the data can be found in section 3.

\begin{tabular}{|c|c|c|c|c|c|c|c|c|c|c|c|c|c|c|c|c|c|c|}
\hline Country & Covgdp & vdep & Age & Polity & Democ & Autoc & Xconst & Coalition I & owcap N & Nplast & Smlbnk & School & Literacy I & Pop65 & Restrict St & ucture & Property $\mathrm{C}$ & Gdpcap \\
\hline Argentina & 3.9 & 14.3 & 21 & 7.2 & 7.2 & 0.0 & 5.2 & 0 & 94.78 & 9.4 & 2.86 & 83.06 & 96.59 & 13.33 & 1 & 0.13 & 2 & 7,935 \\
\hline Austria & 0.9 & 1.1 & 21 & 10.0 & 10.0 & 0.0 & 7.0 & 0.61 & 93.27 & 2.2 & 2.69 & 100.24 & & 18.51 & 1 & -1.86 & 1 & 32,763 \\
\hline Bahamas & 3.1 & 4.5 & & 1 & & & & 0 & 58.45 & & 8.94 & & & & & & 1 & 13,928 \\
\hline Bangladesh & 5.5 & 21.1 & 16 & 5.0 & 5.5 & 0.5 & 4.7 & 0.04 & 85.79 & 43.1 & 8.91 & 35.74 & 39.74 & 5.08 & 3 & -1.70 & 4 & 373 \\
\hline Belarus & 1.9 & 17.4 & & -0.7 & 3.2 & 3.9 & 4.1 & 0 & 49.10 & & 6.67 & 90.00 & 99.51 & 16.10 & 3 & & 4 & 1,430 \\
\hline Belgium & 1.0 & 1.0 & 26 & 10.0 & 10.0 & 0.0 & 7.0 & 1 & 97.75 & 0.6 & 0.76 & 145.27 & & 19.97 & 1 & -0.18 & 1 & 30,830 \\
\hline Bosnia and Herz. & 2.2 & 11.8 & & 2 & & & & & 56.76 & 15.0 & 23.92 & 68.41 & & 11.09 & 1 & & 5 & 1,526 \\
\hline Brazil & 3.1 & 12.8 & 26 & 8.0 & 8.0 & 0.0 & 6.0 & 0 & 83.24 & 3.4 & 3.26 & 69.69 & 84.24 & 7.07 & 1 & -0.09 & 3 & 4,624 \\
\hline Bulgaria & 2.2 & 9.5 & & 8.0 & 8.0 & 0.0 & 7.0 & 0 & 43.04 & 6.4 & 12.62 & 84.86 & 98.14 & 18.65 & 3 & -1.74 & 3 & 1,503 \\
\hline Canada & 1.8 & 3.0 & 33 & 10.0 & 10.0 & 0.0 & 7.0 & 0 & 92.55 & 0.7 & 1.56 & 105.53 & & 15.30 & 1 & 0.15 & 1 & 22,541 \\
\hline Colombia & 3.8 & 18.8 & 15 & 7.8 & 7.8 & 0.0 & 6.4 & 0 & 52.96 & & 13.68 & 67.05 & 90.96 & 6.95 & & -0.79 & 3 & 2,285 \\
\hline Croatia & 2.8 & 6.5 & & -2.8 & 1.2 & 4.0 & 3.3 & 0 & 87.49 & 15.5 & 6.85 & 82.83 & 97.97 & 16.26 & 1 & -0.96 & 4 & 5,146 \\
\hline Cyprus & 1.6 & 1.5 & & 10.0 & 10.0 & 0.0 & 7.0 & 0 & 54.99 & & 3.22 & 83.28 & 96.46 & 14.85 & 1 & -0.63 & 2 & 14,063 \\
\hline Czech Republic & 2.4 & 3.5 & & 10.0 & 10.0 & 0.0 & 7.0 & 0.22 & 62.72 & 27.0 & 7.50 & 88.47 & & 16.40 & 1 & -0.82 & 2 & 5,311 \\
\hline Denmark & 1.2 & 2.3 & 12 & 10.0 & 10.0 & 0.0 & 7.0 & 0.74 & 98.08 & 0.1 & 0.90 & 124.77 & & 18.41 & 1 & 0.45 & 1 & 38,521 \\
\hline Dominican Rep. & 5.3 & 18.9 & 38 & 6.7 & 6.7 & 0.0 & 5.5 & 0 & 67.94 & & 18.83 & & & & & & 4 & 2,056 \\
\hline El Salvador & 3.0 & 7.0 & & 6.9 & 6.9 & 0.0 & 5.0 & 0 & 52.06 & 2.9 & 10.96 & & & & 2 & & 2 & 1,751 \\
\hline Estonia & 0.3 & 1.0 & & 6.0 & 7.0 & 1.0 & 7.0 & 0 & 7.67 & 2.0 & 7.67 & 105.21 & 99.80 & 17.06 & 1 & 0.14 & 2 & 4,431 \\
\hline Finland & 1.0 & 2.1 & 31 & 10.0 & 10.0 & 0.0 & 7.0 & 1 & 29.00 & 0.9 & 9.78 & 119.29 & & 17.89 & 2 & 0.84 & 1 & 32,024 \\
\hline France & 3.1 & 4.6 & 20 & 9.0 & 9.0 & 0.0 & 6.0 & 1 & 89.40 & 6.6 & 2.21 & 110.43 & & 19.20 & 1 & -0.23 & 2 & 29,811 \\
\hline Germany & 0.9 & 1.0 & 34 & 10.0 & 10.0 & 0.0 & 7.0 & 1 & 87.68 & & 3.72 & 100.72 & & 18.94 & 0 & -0.90 & 1 & 32,623 \\
\hline Greece & 2.0 & 3.7 & & 10.0 & 10.0 & 0.0 & 7.0 & 0.13 & 65.73 & 4.0 & 15.23 & 95.34 & 96.73 & 19.70 & 2 & 0.48 & 2 & 13,105 \\
\hline Guatemala & 1.5 & 8.3 & & 5.3 & 5.8 & 0.6 & 4.4 & 0 & 65.35 & 7.1 & 18.66 & 27.56 & 66.83 & 6.21 & 2 & -2.98 & 3 & 1,562 \\
\hline Honduras & 7.3 & 19.3 & & 6.2 & 6.2 & 0.0 & 5.0 & 0 & 66.49 & & 19.81 & 32.06 & 73.14 & 5.62 & 1 & -1.37 & 3 & 711 \\
\hline Hungary & 0.8 & 2.0 & & 10.0 & 10.0 & 0.0 & 7.0 & 0.30 & 71.96 & 8.2 & 10.01 & 97.67 & 99.27 & 17.43 & 1 & -0.08 & 2 & 5,326 \\
\hline
\end{tabular}




\begin{tabular}{|c|c|c|c|c|c|c|c|c|c|c|c|c|c|c|c|c|c|c|}
\hline Iceland & 0.7 & 1.8 & 15 & & & & & 1 & 53.93 & 2.1 & 11.39 & 108.94 & & 15.03 & 1 & -0.54 & 1 & 31,304 \\
\hline India & 4.9 & 11.4 & 39 & 8.6 & 8.6 & 0.0 & 7.0 & 0.30 & 71.19 & 15.0 & 8.68 & 49.03 & 55.25 & 7.27 & 3 & 0.28 & 3 & 459 \\
\hline Ireland & 0.9 & 1.0 & 11 & 10.0 & 10.0 & 0.0 & 7.0 & 0.74 & 74.95 & & 9.61 & 116.41 & & 14.77 & 3 & -0.32 & 1 & 27,741 \\
\hline Italy & 6.0 & 11.4 & 13 & 10.0 & 10.0 & 0.0 & 7.0 & 0.74 & 94.11 & 11.9 & 1.51 & 93.52 & 98.30 & 20.31 & 1 & -0.41 & 2 & 20,885 \\
\hline Jamaica & 1.6 & 4.1 & 2 & 9.3 & 9.3 & 0.0 & 7.0 & 0 & 45.96 & 2.8 & 5.56 & 74.91 & 85.81 & 10.80 & 2 & 0.10 & 2 & 2,115 \\
\hline Kazakhstan & 1.1 & 11.1 & 1 & -3.6 & 1.0 & 4.6 & 2.4 & 0 & 79.38 & 1.0 & 13.35 & 86.93 & & 9.56 & 0 & 0.17 & 4 & 1,515 \\
\hline Kenya & 3.8 & 10.7 & 15 & -4.1 & 0.7 & 4.8 & 3.0 & 0 & 84.00 & 35.0 & 9.62 & 26.06 & 79.73 & 4.99 & 3 & -0.65 & 3 & 328 \\
\hline Latvia & 0.6 & 2.8 & 2 & 8.0 & 8.0 & 0.0 & 7.0 & 0.67 & 42.92 & 6.0 & 19.01 & 85.91 & 99.80 & 17.44 & 1 & -0.94 & 3 & 2,603 \\
\hline Lebanon & 0.9 & 0.36 & 33 & & & & & 0 & 80.61 & 5.2 & 7.80 & 82.28 & 84.66 & 8.60 & 3 & -1.85 & 3 & 2,891 \\
\hline Lithuania & 3.5 & 20.1 & 4 & 10.0 & 10.0 & 0.0 & 7.0 & 0 & 94.52 & 5.0 & 4.01 & 88.63 & 99.51 & 15.95 & 1 & -0.10 & 3 & 2,167 \\
\hline Luxembourg & 0.5 & 0.15 & 11 & & & & & 1 & 63.70 & 0.2 & 4.71 & 89.35 & & 17.44 & 1 & 0.58 & 1 & 56,372 \\
\hline Macedonia, FYR & 4.5 & 30.9 & 4 & 6.0 & 6.0 & 0.0 & 5.0 & 0 & 86.34 & 44.0 & 10.98 & 68.22 & & 12.22 & 3 & -3.59 & & 2,535 \\
\hline Morocco & 4.1 & 6.5 & 7 & -6.9 & 0.0 & 6.9 & 2.8 & 0 & 27.56 & 7.0 & 26.73 & 38.76 & 46.44 & 6.37 & 3 & -0.45 & 3 & 1,370 \\
\hline Netherlands & 0.9 & 0.9 & 21 & 10.0 & 10.0 & 0.0 & 7.0 & 1 & 96.79 & & 1.32 & 129.34 & & 16.46 & 1 & 0.16 & 1 & 30,967 \\
\hline Nigeria & 1.5 & 8.5 & 12 & -3.9 & 0.8 & 4.7 & 1.8 & 0 & 81.48 & 8.2 & 11.51 & 31.17 & 60.14 & 5.53 & 1 & -0.25 & 3 & 254 \\
\hline Norway & 7.6 & 14.8 & 39 & 10.0 & 10.0 & 0.0 & 7.0 & 0.83 & 93.48 & & 4.03 & 118.17 & & 19.48 & & -0.74 & 1 & 37,954 \\
\hline Oman & 6.3 & 24.2 & 5 & -9.1 & 0.0 & 9.1 & 1.9 & 0 & 78.35 & 5.9 & 15.51 & 67.00 & 67.68 & 4.50 & 3 & -0.23 & 2 & 5,668 \\
\hline Peru & 9.1 & 36.5 & 8 & 2.0 & 3.9 & 1.9 & 3.7 & 0 & 73.76 & 18.1 & 9.52 & 74.04 & 88.87 & 7.02 & 1 & -0.04 & 2 & 2,368 \\
\hline Philippines & 2.3 & 4.8 & 37 & 8.0 & 8.0 & 0.0 & 6.2 & 0 & 77.31 & 13.8 & 8.77 & 76.91 & 94.65 & 5.50 & 1 & 0.27 & 2 & 1,167 \\
\hline Poland & 2.9 & 7.3 & 5 & 8.3 & 8.3 & 0.0 & 6.4 & 0 & 67.66 & 4.7 & 5.95 & 97.02 & 99.70 & 14.69 & 2 & -0.45 & 2 & 4,223 \\
\hline Portugal & 2.1 & 2.0 & 8 & 10.0 & 10.0 & 0.0 & 7.0 & 0.09 & 82.12 & 1.2 & 5.06 & 111.27 & 91.10 & 18.22 & 1 & -0.87 & 2 & 12,794 \\
\hline Romania & 1.3 & 7.8 & 4 & 6.4 & 6.4 & 0.0 & 5.5 & 0.22 & 69.04 & 40.0 & 6.21 & 78.82 & 97.86 & 15.68 & 3 & -1.72 & 4 & 1,489 \\
\hline Slovak Republic & 2.0 & 2.8 & 4 & 7.8 & 7.8 & 0.0 & 6.4 & 1 & 53.78 & 9.6 & 16.10 & 88.45 & & 14.11 & 2 & -1.69 & 3 & 4,160 \\
\hline Spain & 1.5 & 1.9 & 23 & 10.0 & 10.0 & 0.0 & 7.0 & 0.04 & 75.84 & 0.1 & 3.56 & 114.86 & 97.35 & 19.10 & 1 & -0.36 & 2 & 17,798 \\
\hline Sri Lanka & 1.6 & 4.7 & 13 & 5.0 & 6.0 & 1.0 & 5.0 & 0.13 & 79.74 & & 13.74 & 73.94 & 90.94 & 8.36 & 0 & -0.93 & 3 & 860 \\
\hline Sweden & 1.1 & 2.8 & 4 & 10.0 & 10.0 & 0.0 & 7.0 & 0.70 & 97.90 & & 1.42 & 149.38 & & 21.41 & 1 & 0.22 & 2 & 31,206 \\
\hline Switzerland & 0.5 & 0.42 & 16 & 10.0 & 10.0 & 0.0 & 7.0 & 1 & 96.02 & 6.0 & 0.91 & 98.79 & & 18.61 & 0 & 0.30 & 1 & 46,737 \\
\hline Taiwan, China & 2.3 & 1.4 & 15 & 6.4 & 6.9 & 0.6 & 5.0 & 0 & 61.56 & & 18.09 & & & & 3 & & 1 & 15,802 \\
\hline Tanzania & 1.2 & 8.6 & 6 & -3.2 & 1.2 & 4.4 & 3.0 & 0 & 90.58 & & 6.25 & & & & & & 3 & 190 \\
\hline Trinidad \& Tob. & 1.3 & 3.0 & 14 & 9.4 & 9.4 & 0.0 & 7.0 & 0.09 & 43.22 & 2.1 & 17.42 & 76.67 & 93.23 & 9.01 & 1 & 0.08 & 1 & 5,324 \\
\hline Uganda & 6.7 & 68.7 & 6 & -4.8 & 0.0 & 4.8 & 2.5 & 0 & & & & & & & & & 2 & 348 \\
\hline Ukraine & 0.3 & 2.1 & 2 & 6.5 & 6.5 & 0.0 & 4.5 & 0 & 55.96 & & 12.37 & 92.79 & 99.57 & 16.94 & & -0.17 & 4 & 896 \\
\hline United Kingdom & 1.3 & 1.2 & 18 & 10.0 & 10.0 & 0.0 & 7.0 & 0.04 & 96.70 & 2.2 & 0.82 & 140.88 & & 19.48 & 1 & 0.28 & 1 & 21,667 \\
\hline United States & 2.9 & 7.7 & 66 & 10.0 & 10.0 & 0.0 & 7.0 & 0 & 69.49 & 0.6 & 3.33 & 96.51 & & 15.87 & 2 & 0.09 & 1 & 31,996 \\
\hline Venezuela & 1.2 & 8.3 & 15 & 8.0 & 8.0 & 0.0 & 5.8 & 0 & 58.32 & 1.6 & 4.34 & 47.75 & 91.75 & 6.56 & 1 & -0.26 & 3 & 3,301 \\
\hline Vietnam & 5.3 & 16.4 & 1 & -7.0 & 0.0 & 7.0 & 3.0 & 0 & 93.34 & & 5.27 & 56.45 & 92.74 & 7.97 & 3 & & 5 & 356 \\
\hline
\end{tabular}

